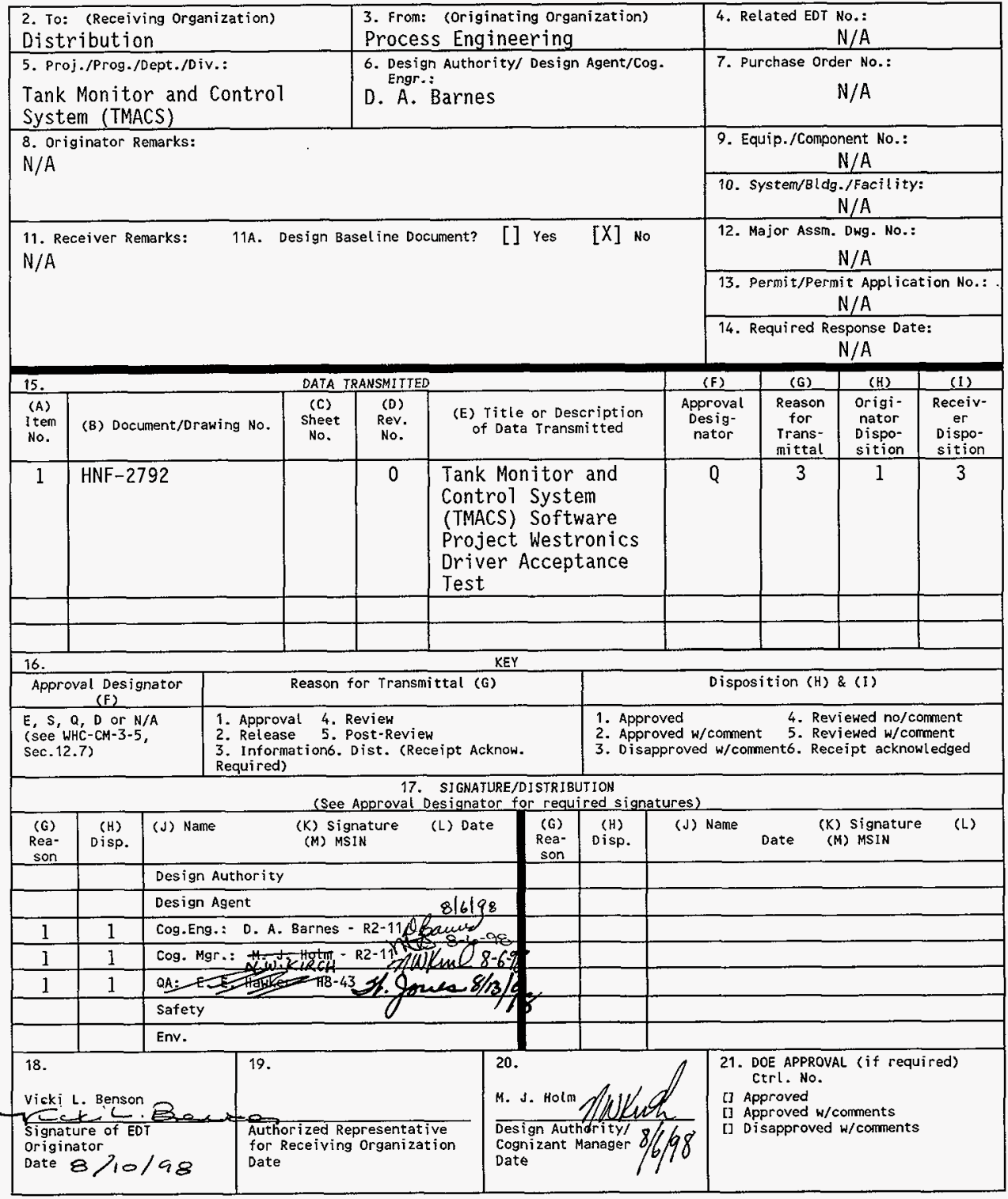




\section{Tank Monitor and Control System (TMACS) Software Project Westronics Driver Acceptance Test}

Joseph A. Glasscock

Lockheed Martin Services, Inc., Richland, WA 99352

U.S. Department of Energy Contract DE-AC06-96RL13200

EDT: 625027

Org Code: 7E062

B\&R Code: EW3120071
UC: $605,4 C-2000$

Charge Code: NF23E and HJ213500

Total Pages: 28

Key Words: TMACS, Westronics, Acceptance Test, Surveillance Systems, driver software

Abstract: The acceptance test for the Westronics driver. This driver connects the Westronics Smart Multiplexer with the TMACS monitoring system.

Westronics is a registered trademark of Westronics, Inc.

Unix is a trademark of X/Open company, Ltd.

TRADEMARK DISCLAIMER. Reference herein to any specific comercial product, process, or service by trade name, trademark, manufacturer, or otherwise, does not necessarily constitute or imply its endorsement, recommendation, or favoring by the United States Government or any agency thereof or its contractors or subcontractors.

Printed in the United States of America. To obtain copies of this document, contact: Document control Services, P.O. Box 950, Mailstop H6-08, Richland WA 99352, Phone (509) 372-2420; Fax (509) 376-4989.
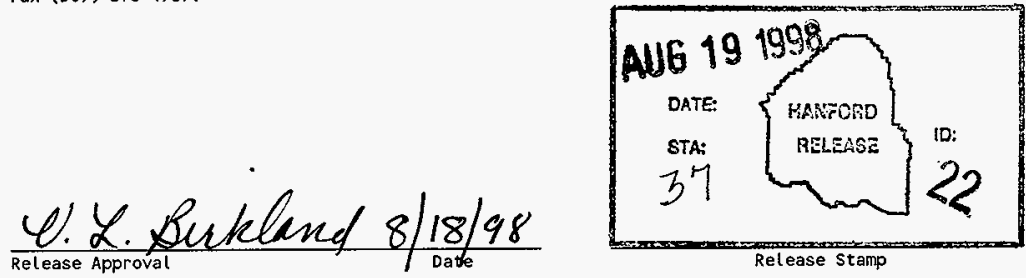

\section{Approved for Public Release}


TANK MONITOR AND CONTROL SYSTEM

(TMACS)

SOFTWARE PROJECT

WESTRONICS $($ DRIVER ACCEPTANCE TEST

Steven C. Cantrell

Numatec Hanford Company

Ronald R. Wandling

Joe Glasscock

LMSI Software Development and Integration 


\begin{tabular}{|c|c|c|}
\hline \multirow{3}{*}{$\begin{array}{l}\text { Test Procedure ID } \\
\text { UTP } 07.08 .00-00 \\
\text { Revision } 0\end{array}$} & TEST DESIGN SPECIFICATION ID: $\mathbf{0 7 . 0 8 . 0 0 - 0 0}$ & TITLE: Westronics Driver Acceptance Test \\
\hline & TESTING PHASE: Acceptance Test & PLATFORM: UNIX Page 2 of 27 \\
\hline & & \\
\hline
\end{tabular}

\section{FEATURES TO BE TESTED:}

This procedure tests the functionality of the TMACS Westronics driver software for user acceptance. The driver is tested while communicating to a Westronics multiplexer in RTU mode with and without a code-operated switch.

\section{TEST CASE DESCRIPTIONS:}

Table 1. Test Cases

UTP 07.04.00 -00 -1. Test Embedded Mode Communication without Code Operated Switch

UTP 07.04.00 -00 -2. Test Checksum Errors While in Embedded Mode

UTP 07.04.00-00 -3. Test Westronics Exception Errors While in Embedded Mode

UTP $07.04 .00-00-4$. Test Station Mismatch Errors While in Embedded Mode

UTP 07.04.00 -00 -5. Test Non-responsive Westronics Stations While in Embedded Mode

UTP 07.04.00 -00 -6. Test Polling Rate Changes while in Embedded Mode

UTP 07.04.00-00 -7. Test Normal Communication through Code Operated Switch While in Embedded Mode

UTP 07.04.00 -00 -8. Verify Log Messages from Driver - Not applicable in UNIX environment - Do Not Run

\section{Table 2. Appendices}

Appendix A: Westronics Emulator Program Display and Commands

Appendix B: Emulator Configuration for Normal Operation

Appendix C: Emulator Configuration for Single Checksum Errors

Appendix D: Emulator Configuration for Multiple Checksum Errors

Appendix E: Emulator Configuration for Single Exception Error

Appendix F: Emulator Configuration for Station Mismatch Error

\section{DEPENDENCIES:}

The Westronics driver being tested must be running on the test computer. 


\begin{tabular}{l|ll|}
\hline Test Procedure ID & TEST DESIGN SPECIFICATION ID: 07.08.00-00 & TITLE: Westronics Driver Acceptance Test \\
UTP 07.08.00 -00 & TESTING PHASE: Acceptance Test & PLATFORM: UNIX \\
\cline { 2 - 3 } Revision 0 & &
\end{tabular}

\section{REFERENCES:}

The acceptance criteria for this Test Procedure are taken from HNF-2607, the Functional Requirements for the Westronics Multiplexer Interface to the Tank Monitor and Control System (TMACS).

The Westronics commands are detailed in the Westronics Smart Multiplexer User Manual, Part Number M0100144-01, by Westronics, Inc., issued June, 1996 and in the Modicon Modbus Protocol at Internet URL http://www.modicon.com/techpubs/toc7.html.

\section{FEATURE PASSIFAIL CRITERIA:}

- The actual result from each test case must match the expected result.

- All incident reports generated while executing the test procedure must be resolved or closed.

\section{TESTER INFORMATION}

The TMACS system is an application built using the $\mathrm{G} 2$ Real-Time Expert System. The instructions for using the mouse, mouse buttons, and keyboard are given below.

The majority of user control of the system involves pointing at objects on the computer screen using the POINTER. The pointer is an arrow that is pointing to the upper left of the screen. When a user moves the mouse, the pointer moves on the screen.

The G2 system treats the left and right mouse buttons as if they were a single button. Whenever the use of a mouse button is required the user is free to use either of these buttons.

The following terms are used to describe actions performed with the mouse:

To MOVE the pointer, slide the mouse with no buttons pressed.

To POINT to a push-button or object, move the pointer to the appropriate place on the screen.

To CLICK on an object, first move your mouse so that the screen pointer rests on the object. Then, press the mouse button and release immediately without moving the mouse. 


\begin{tabular}{|c|c|c|}
\hline Test Procedure ID & TEST DESIGN SPECIFICATION ID: 07.08.00 -00 & TITLE: Westronics Driver Acceptance Test \\
\hline UTP $07.08 .00-00$ & TESTING PHASE: Acceptance Test & PLATFORM: UNIX $\quad$ Page 4 of 27 \\
\hline
\end{tabular}

To DRAG an object with the mouse, first move the mouse so that the screen pointer rests on the object. Then, press the mouse button and move the mouse without releasing the button. The object moves along with the screen pointer as you move the mouse. Release the button when the object is in the desired place. To drag a window in TMACS place the mouse in a blank area around the margin of the window and drag. (Note: the drag function is not provided for all windows.)

If the G2 screen becomes unreadable or objects overwrite each other the screen can be redrawn by typing Control-C. (Hold down the "Control" key while typing the letter $\mathrm{C}$ ).

The Westronics stations associated with an Westronics interface can be displayed in the $\mathrm{G} 2$ Inspector workspace. This is very useful in showing the sample frequency for each station and the stations available for an interface. The command needed is: "Display a table of the names, objindex, polling-freq, and last-recorded-value of every Westronics-station $S$ such that the text of the gsi-interface-name of $S=$ "Westronics-XX" where the "XX" is replaced by the number of the Westronics interface of interest.

\section{Westronics Multiplexer Layout}

Each Westronics unit may have up to 5 slots: Each slot may contain up to 20 sample points. The numbering for each point for each slot is:

- Slot 1 starts at point 10 and goes thorough 29 .

- Slot 2 starts at point 30 and goes thorough 49 .

- Slot 3 starts at point 50 and goes thorough 69 .

- Slot 4 starts at point 70 and goes thorough 89 .

- Slot 5 starts at point 90 and goes thorough 109.

\section{Emulator Operation}

The emulator to use is westemul.exe.

Refer to Appendix A for basic emulator menus and operation.

\section{PRE-TEST INSPECTION AND SETUP REQUIREMENTS}

This Test Procedure is run using the Westronics driver software developed for production. 


\begin{tabular}{l|ll|}
\hline $\begin{array}{l}\text { Test Procedure ID } \\
\text { UTP 07.08.00 -00 }\end{array}$ & TEST DESIGN SPECIFICATION ID: 07.08.00 -00 & TITLE: Westronics Driver Acceptance Test \\
Revision 0 & TESTING PHASE: Acceptance Test & PLATFORM: UNIX \\
\cline { 2 - 3 } & &
\end{tabular}

The hardware required is:

- The TMACS development computer(s).

- At least an 8-port serial multiplexer is attached to the workstation where the driver is to be tested.

- The Westronics emulator (currently on a separate computer). The emulator can be connected to any port on the driver test machine.

- (Optional if the emulator can support the code-operated switch.) A code-operated switch that can be plugged between the Westronics emulator and the driver test machine.

- A serial analyzer used to monitor the communication between TMACS and the external devices (used to view the code-operated switch commands).

To set this test up the Test Administrator must perform the following steps:

1. Verify that the Westronics Station Objects in the knowledge base use a gsi-interface connected to the Westronics driver.

2. Verify that the Westronics Station Objects have unique station addresses. For release 10.6 of TMACS there will be only analog points supported by the Westronics driver.

3. Verify that the gsi-interface is configured to point to the socket for the driver to be tested (e.g., socket 22214, 22215...) and that the driver being tested will listen on that socket.

4. Make sure the computer that will run the Westronics bridge software is connected to the Westronics emulator program through a port on the serial multiplexer on the computer.

5. If used, make sure a serial anaiyzer is tied into the connection between the Westronics bridge and the code-operated switch. (This is necessary to observe the data coming across the communication line for the code-operated switch).

6. Verify that the gsi-interface will configure the driver to use the serial port where the emulatorMestronics is connected.

7.- Start the Westronics bridge. 


\begin{tabular}{|l|ll|}
\hline $\begin{array}{l}\text { Test Procedure ID } \\
\text { UTP 07.08.00 -00 }\end{array}$ & $\begin{array}{l}\text { TEST DESIGN SPECIFICATION ID: 07.08.00 -00 } \\
\text { TESTING PHASE: Acceptance Test }\end{array}$ & $\begin{array}{l}\text { TITLE: Westronics Driver Acceptance Test } \\
\text { Revision } 0\end{array}$
\end{tabular}

\section{TEST CASES WITH EXPECTED RESULTS:}

\section{UTP 07.04.00 -00 - 1. Test Embedded Mode Communication without Code Operated Switch}

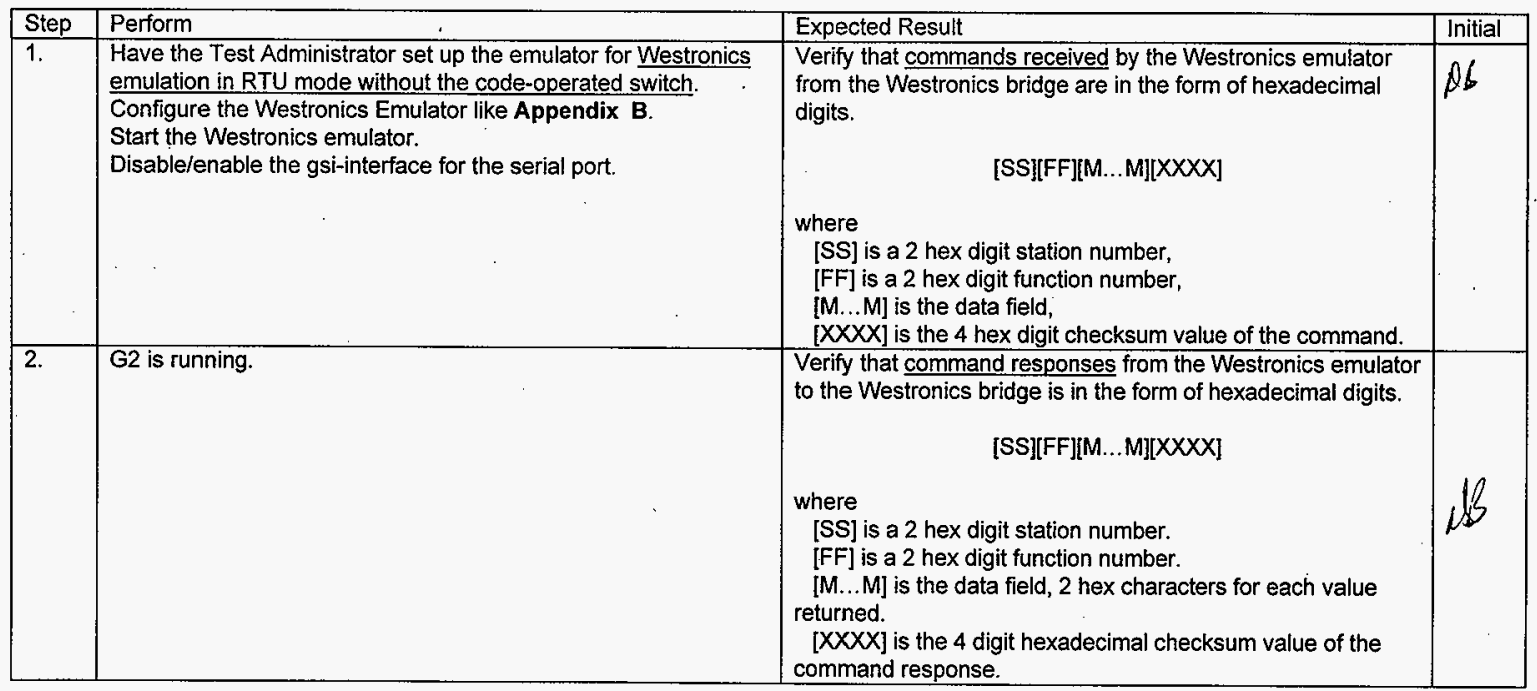




\begin{tabular}{|l|ll|}
\hline $\begin{array}{l}\text { Test Procedure ID } \\
\text { UTP 07.08.00-00 }\end{array}$ & TEST DESIGN SPECIFICATION ID: 07.08.00 -00 & TITLE: Westronics Driver Acceptance Test \\
Revision 0 & TESTING PHASE: Acceptance Test & PLATFORM: UNIX \\
\cline { 2 - 3 } & & \\
\hline
\end{tabular}

UTP 07.04.00 -00 -2. Test Checksum Errors While in Embedded Mode

\begin{tabular}{|c|c|c|c|}
\hline Step & Perform & Expected Result & Initial \\
\hline 2. & $\begin{array}{l}\text { Start the Westronics Emulator with display of received and } \\
\text { transmitted messages to the screen enabled. }\end{array}$ & $\begin{array}{l}\text { For the Westronics station specified, } \\
\text { Verify that a sequence similar to that shown in Appendix C } \\
\text { is displayed by the emulator after a single checksum error. } \\
\text { This error will occur about every third poll. }\end{array}$ & ofs \\
\hline 3. & $\mathrm{G} 2$ is running. & $\begin{array}{l}\text { Verify that you do not see a white alarm stating a Checksum } \\
\text { error has occurred displayed on the G2 MOST RECENT } \\
\text { ALARM window. This is because a retry is attempted before } \\
\text { a checksum error will be reported. }\end{array}$ & ab \\
\hline 4. & $\begin{array}{l}\text { Pause G2. } \\
\text { Configure the Westronics Emulator like Appendix D. } \\
\text { Resume G2. }\end{array}$ & $\begin{array}{l}\text { Verify that TMACS is running. } \\
\text { Verify that the emulator is running. }\end{array}$ & $\alpha B$ \\
\hline 5. & $\mathrm{G} 2$ is running. & $\begin{array}{l}\text { For the Westronics station specified: } \\
\text { Verify that a sequence similar to that shown in Appendix D } \\
\text { is displayed by the emulator after a checksum error. This } \\
\text { error will occur about every third poll. }\end{array}$ & 16 \\
\hline
\end{tabular}


HNF-2792 Rev. 0

\begin{tabular}{|c|c|c|}
\hline Test Procedure ID & TEST DESIGN SPECIFICATION ID: $07.08 .00-00$ & TITLE: Westronics Driver Acceptance Test \\
\hline UTP 07.08.00 -00 & TESTING PHASE: Acceptance Test & PLATFORM: UNIX \\
\hline
\end{tabular}

\section{UTP 07.04.00 -00 -3. Test Westronics Exception Errors While in Embedded Mode}

\begin{tabular}{|c|c|c|c|}
\hline Step & Perform & Expected Result & Initial \\
\hline 1. & $\begin{array}{l}\text { Pause } \mathrm{G} 2 \text {. } \\
\text { Configure the Westronics Emulator like Appendix } E \text { using any } \\
\text { valid exception code. Valid exception code numbers are listed in } \\
\text { Appendix } E \text {. } \\
\text { Resume } G 2 \text { again when this is completed. }\end{array}$ & Verify that the emulator is communicating with TMACS. & $M$ \\
\hline 2. & G2 is running. & $\begin{array}{l}\text { For the Westronics station specified: } \\
\text { Verify that the sequence similar to that shown in Appendix E } \\
\text { is displayed after a Westronics reject error. The error will } \\
\text { occur about every third poll to the selected address. }\end{array}$ & 16 \\
\hline
\end{tabular}




\begin{tabular}{|c|c|c|}
\hline Test Procedure ID & TEST DESIGN SPECIFICATION ID: 07.08.00-00 & TITLE: Westronics Driver Acceptance Test \\
\hline UTP $07.08 .00-00$ & TESTING PHASE: Acceptance Test & PLATFORM: UNIX $\quad$ Page 9 of 27 \\
\hline
\end{tabular}

\section{UTP 07.04.00 -00 -4. Test Station Mismatch Errors While in Embedded Mode}

In this section we will test the situation when the driver queries one Westronics station and receives an answer from a different station. When the emulator receives a message for the station with the Selected Address it will return a response with the Mux Address. For example, with Selected Address $=2$. and Mux Address $=1$, polls to station 2 will be returned as if they came from station 1; the frequency of failure is set by the Error Rate.

\begin{tabular}{|c|c|c|c|}
\hline Step & Perform & Expected Result & Initial \\
\hline
\end{tabular}




\begin{tabular}{|c|c|c|}
\hline \multirow{3}{*}{$\begin{array}{l}\text { Test Procedure 1D } \\
\text { UTP 07.08.00 -00 } \\
\text { Revision } 0\end{array}$} & TEST DESIGN SPECIFICATION ID: 07.08.00 -00 & \multirow{2}{*}{$\begin{array}{l}\text { TITLE: Westronics Driver Acceptance Test } \\
\text { PLATFORM: UNIX }\end{array}$} \\
\hline & TESTING PHASE: Acceptance Test & \\
\hline & & \\
\hline
\end{tabular}

\section{UTP 07.04.00 -00 -5. Test Non-responsive Westronics Stations While in Embedded Mode}

In this section we will test the situation when an Westronics station stops communicating with the Westronics bridge that the bridge will not attempt to re-send a command to that station. We will also verify that when communication is restored that the Westronics bridge will oniy send a retry when a checksum error is received from the station. The serial analyzer is needed to verify the operation of TMACS for these tests.

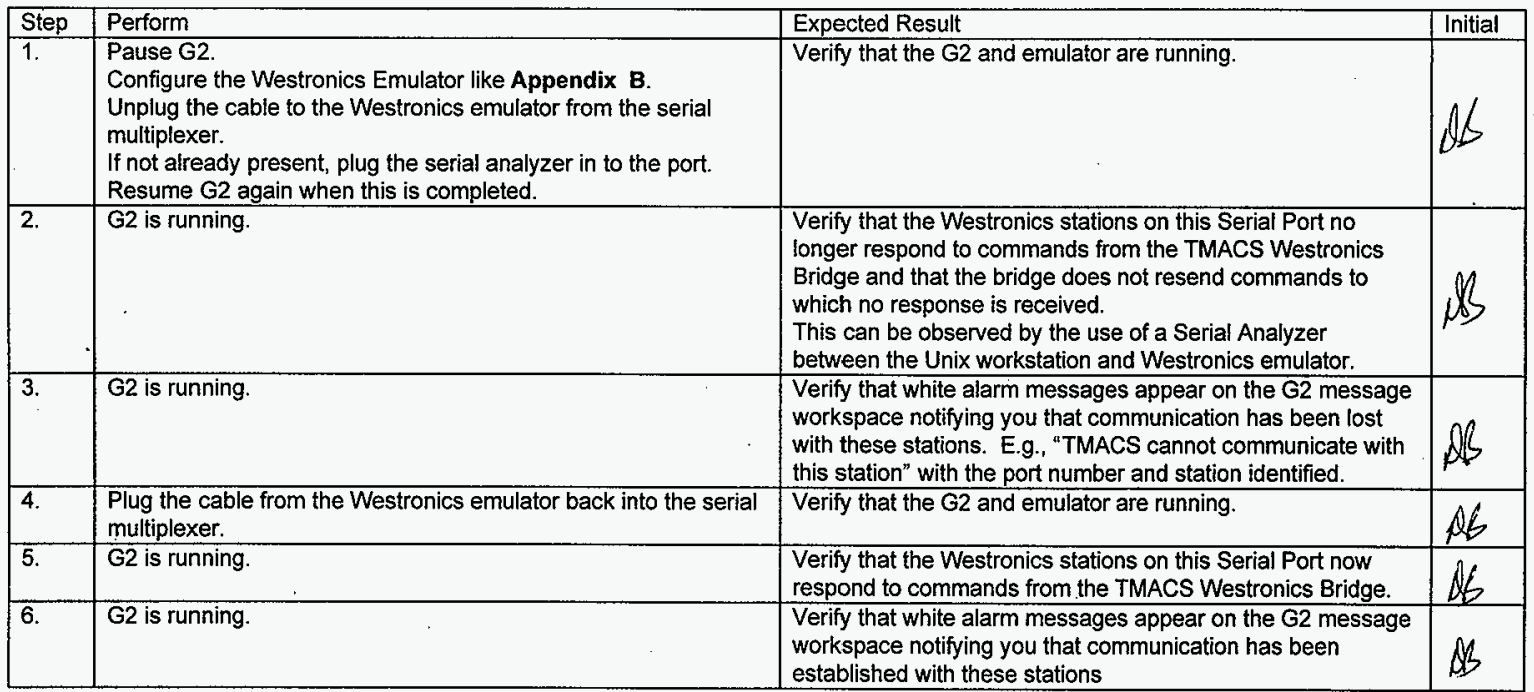




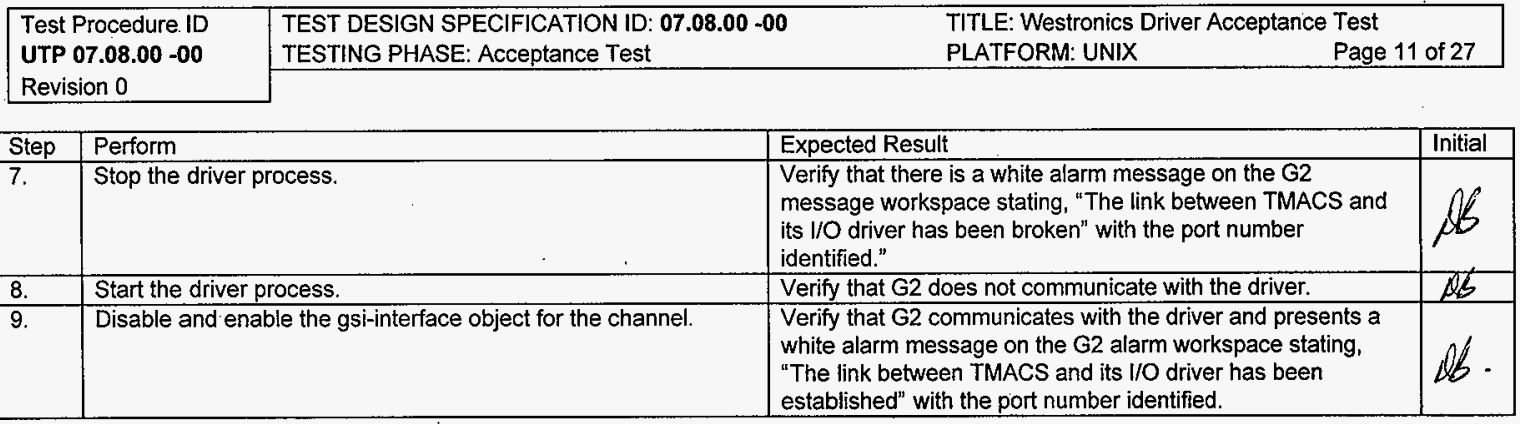

\section{UTP 07.04.00 -00 -6. Test Polling Rate Changes while in Embedded Mode}

\begin{tabular}{|c|c|c|c|}
\hline Step & Perform & Expected Result & Initial \\
\hline 2. & $\begin{array}{l}\text { Login in the administrator mode and bring up the display of an } \\
\text { Westronics object that is connected to the test port. } \\
\text { Observe the sample frequency of the Westronics object. }\end{array}$ & 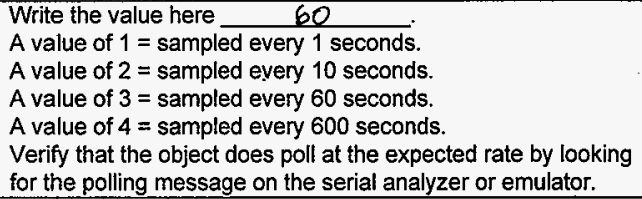 & aS \\
\hline 3. & $\begin{array}{l}\text { Change the sample frequency of the Westronics object. Valid } \\
\text { values as of } 6 / 1 / 98 \text { are } 1,2,3 \text { and } 4 \text {. }\end{array}$ & $\begin{array}{l}\text { Write the new value here } \frac{10}{\text { Verify that the object is polled only at the new rate by looking }} \\
\text { for the polling message on the serial analyzer. }\end{array}$ & MS. \\
\hline
\end{tabular}


HNF-2792 Rev. 0

\begin{tabular}{|c|c|c|c|c|c|}
\hline \multirow{2}{*}{\multicolumn{2}{|c|}{$\begin{array}{l}\text { Test Procedure ID } \\
\text { UTP 07.08.00 -00 } \\
\text { Revision 0 }\end{array}$}} & \multirow{2}{*}{$\begin{array}{l}\text { TEST DESIGN SPECIFICATION ID: } \mathbf{0 7 . 0 8 . 0 0 - 0 0} \\
\text { TESTING PHASE: Acceptance Test }\end{array}$} & \multirow{2}{*}{\multicolumn{3}{|c|}{ TITLE: Westronics Driver Acceptance Test }} \\
\hline & & & PLATFORM: UNIX & & \\
\hline 5. & \multicolumn{2}{|c|}{$\begin{array}{l}\text { Change the sample frequency of the Westronics object to the } \\
\text { original value. }\end{array}$} & $\begin{array}{l}\text { Verify that the object is polled only a } \\
\text { for the polling message on the serial }\end{array}$ & $\begin{array}{l}\text { ooking } \\
\text { ator. }\end{array}$ & QQS. \\
\hline
\end{tabular}

\section{UTP 07.04.00 -00 -7. Test Normal Communication through Code Operated Switch While in Embedded Mode}

As of May, 1998, the Westronics emulator does not support emulation of the code-operated switch. To run this section a code-operated switch must be connected between the Westronics driver serial port and the Westronics emulator or test unit.

A serial analyzer is needed to see the arming character and channel selection character for the code-operated switch. This analyzer should be connected between the driver serial port and the code-operated switch since the code-operated switch does not pass on the arming and port selection characters.

\begin{tabular}{|c|c|c|c|}
\hline Step & Perform & Expected Result & Initial \\
\hline 1. & $\begin{array}{l}\text { Have the Test Administrator set up the test for Westronics } \\
\text { emulation mode using the code-operated switch. Configuration } \\
\text { for the Westronics Emulator is given in Appendix B except that } \\
\text { the code-operated switch is enabled. When the Westronics } \\
\text { emulator, code-operated switch, and Westronics driver software } \\
\text { are running, enable the display of send and received commands } \\
\text { on the emulator. }\end{array}$ & $\begin{array}{l}\text { Verify that commands sent from the port on the slave are in } \\
\text { the form of ASCII hexadecimal digits and ASCll characters: } \\
\qquad[A][P][S S][F F][M \ldots M][X X X X] \\
\text { where } \\
{[A] \text { is the code-operated switch arming character, }} \\
{[P] \text { is the port number character. }} \\
{[S S] \text { is a } 2 \text { hex digit station number, }} \\
{[F F] \text { is a } 2 \text { hex digit function number, }} \\
{[M . . M] \text { is the data field, }} \\
{[X X X X] \text { is the } 4 \text { hex digit checksum value of the command. }}\end{array}$ & $\sqrt{6}$ \\
\hline
\end{tabular}


HNF-2792 Rev. 0

\begin{tabular}{|l|ll|}
\hline $\begin{array}{l}\text { Test Procedure ID } \\
\text { UTP 07.08.00 -00 }\end{array}$ & $\begin{array}{l}\text { TEST DESIGN SPECIFICATION ID: 07.08.00 -00 } \\
\text { TESTING PHASE: Acceptance Test }\end{array}$ & TITLE: Westronics Driver Acceptance Test \\
Revision 0 & & PLATFORM: UNIX \\
\cline { 2 - 3 }
\end{tabular}

\begin{tabular}{|c|c|c|c|}
\hline Step & Perform & Expected Resuit & Initial \\
\hline
\end{tabular}

UTP 07.04.00 -00 -8. Verify Log Messages from Driver - Not applicable in UNIX environment - Do Not Run

\begin{tabular}{|l|l|l|l|}
\hline Step & Perform & Expected Result & Initial \\
\hline 1. & $\begin{array}{l}\text { On the computer running the driver, use the Event Viewer to } \\
\text { check the Event Log for messages from the Westronics Driver. }\end{array}$ & $\begin{array}{l}\text { Verify that there is a startup message dated when the } \\
\text { Westronics driver was started for this testing. }\end{array}$ \\
\hline 2. & & $\begin{array}{l}\text { Verify that there is a shutdown message from step UTP } \\
07.04 .00-00-4 .\end{array}$ & $\begin{array}{l}\text { Verify that there is a startup message from step UTP } \\
07.04 .00-00-4 .\end{array}$ \\
\hline 3. & & $\begin{array}{l}\text { Verify that there are no other driver messages produced as a } \\
\text { result of this testing. }\end{array}$ & \\
\hline 4. & & & \\
\hline
\end{tabular}


\begin{tabular}{|l|ll}
\hline Test Procedure ID & TEST DESIGN SPECIFICATION ID: 07.08.00 -00 TITL: Westronics Driver Acceptance Test
\end{tabular}

UTP 07.08.00 -00

TESTING PHASE: Acceptance Test

PLATFORM: UNIX

Page 14 of 27

Revision 0

\section{Appendix A: Westronics Emulator Program Display and Commands}

\section{Display on startup}

C:ITMACSIEmulator executables>westemui

Term Emulator, Version 1: Press Control-A for a summary of commands

\section{Main Menu for Westronics Emulator Program}

Main Menu

A. Data Format, Baud rate

B. RS-232 control

C. Transmit BREAK signal

D. Upload Text File

E. Download Text File (small buffer)

F. Download Text File (large buffer)

G. Access Menu Character

$H$. Display characters in HEX

1. Enable output poll string

$\mathrm{J}$. Define output poll string

K. Set output poll delay time

L. Configure TMACS Emuiator

Q. EXIT from TERM.

Enter selection (CR to quit menu): 


\begin{tabular}{|l|ll|}
\hline $\begin{array}{l}\text { Test Procedure ID } \\
\text { UTP 07.08.00 -00 } \\
\text { Revision 0 }\end{array}$ & $\begin{array}{l}\text { TEST DESIGN SPECIFICATION ID: 07.08.00 -00 } \\
\text { TESTING PHASE: Acceptance Test }\end{array}$ & TITLE: Westronics Driver Acceptance Test \\
\cline { 2 - 3 } & & PLATFORM: UNIX \\
\hline
\end{tabular}

\section{From the Main menu Option $\mathrm{L}$ brings up the menu:}

\section{CURRENT EMULATOR MODE: Disabled}

\author{
Choice Options Are \\ 1. Disable \\ 2. Acromag \\ 3. Enraf \\ 4. Panalarm \\ 5. Westronics
}

Enter your choice (press Return to exit):

\section{Then Option 5 brings up the menu:}

\section{Westronics Emulator Menu}

1. Read Configuration File

2. Display Configuration Parameter Values

3. Change Configuration Parameter Values

4. Save Configuration To File

5. Enable WESTRONICS Emulator

6. Disable WESTRONICS Emulator

Enter selection (CR to quit menu) :

\section{Then Option 2 brings up the display:}

Display Configuration Parameters WESTRONICS PARAMETERS
1. Code Operated Switch: OFF
2. Tx Delay Time: 0.00
3. Error Rate \%: 0.00
4. Multiple Error: 0 hex, 0 dec
5. Checksum Mask: 0 hex, 0 dec
6. Exception Value: 0 hex, 0 dec
7. Modbus Mode RTU: ON
8. Coil Register: 0 hex, $0 \mathrm{dec}$
9. Status Register: 0 hex, 0 dec
10. Hold Register \#01: 0 hex, 0 dec
11. Hold Register \#02: 0 hex, 0 dec
12. Hold Register \#03: 0 hex, $0 \mathrm{dec}$
13. Hold Register \#04: 0 hex, 0 dec
14. Hold Register \#05: 0 hex, 0 dec
15. Hold Register \#06: 0 hex, 0 dec
16. Hold Register \#07: 0 hex, 0 dec
17. Hold Register \#08: 0 hex, 0 dec
18. Hold Register \#09: 0 hex, 0 dec
19. Hold Register \#10: 0 hex, 0 dec
20. Hold Register \#11: 0 hex, 0 dec

(- Press any key to continue -)

21. Hold Register \#12: 0 hex, 0 dec

22. Hold Register \#13: 0 hex, 0 dec

23. Hold Register \#14: 0 hex, 0 dec

24. Hold Register \#15: 0 hex, 0 dec

25. Hold Register \#16: 0 hex, 0 dec

26. Hold Register \#17: 0 hex, 0 dec 
HNF-2792 Rev. 0

\begin{tabular}{|l|ll|}
\hline Test Procedure ID & TEST DESIGN SPECIFICATION ID: $\mathbf{0 7 . 0 8 . 0 0 - 0 0}$ & TITLE: Westronics Driver Acceptance Test \\
UTP 07.08.00 -00 & TESTING PHASE: Acceptance Test & PLATFORM: UNIX Page 16 of 27 \\
\cline { 2 - 3 } Revision 0 & &
\end{tabular}
27. Hold Register \#18: 0 hex, 0 dec
28. Hold Register \#19: 0 hex, 0 dec
29. Hold Register \#20: 0 hex, 0 dec
30. Mux Address: 0 hex, 0 dec
31. TC Temperature: 130.00
32. Temperature Mux Offset: 5.00
33. Temperature Register Offset: 1.00
34. Selected Address: 0 hex, 0 dec
35. Selected Register: 0 hex, 0 dec
36. Selected TC Temperature: 0.00
(-Press any key to continue -)

\section{Pressing the Enter key brings up the Menu:}

Westronics Emulator Menu

1. Read Configuration File

2. Display Configuration Parameter Values

3. Change Configuration Parameter Values

4. Save Configuration To File

5. Enable WESTRONICS Emulator

6. Disable WESTRONICS Emulator

Enter selection (CR to quit menu) :

From the Westronics Emulator Menu Option 5 enables the Westronics emulator. The emulator will be started when you press the Enter key twice.

When the emulator is operating it recognizes the following commands:

- $\quad "$ " = Display total transmitted responses

- $\quad " B "$ = Audible bell enable, disable

- $\quad$ "F" = Display command identification

- $\quad$ "R" = Display received commands

- $\quad$ "S" = Display sent responses

- $\quad "+"=$ Raise selected temperature

- $\quad$ "." = Lower selected temperature

- $\quad "="$ = Display selected temperature

- "?" = List valid commands

If the bell is used it will upset the timing of the emulator and cause time-out failures in TMACS. Do not use the bell for normal operation. 
HNF-2792 Rev. 0

\begin{tabular}{|l|ll|}
\hline $\begin{array}{l}\text { Test Procedure ID } \\
\text { UTP 07.08.00 -00 }\end{array}$ & TEST DESIGN SPECIFICATION ID: 07.08.00 -00 & TITLE: Westronics Driver Acceptance Test \\
Revision 0 & TESTING PHASE: Acceptance Test & PLATFORM: UNIX \\
\cline { 3 - 3 } & &
\end{tabular}

Appendix B: Emulator Configuration for Normal Operation

Display Configuration Parameters WESTRONICS PARAMETERS

1. Code Operated Switch: OFF

2. Tx Delay Time: 0.00

3. Error Rate \%: 0.00

4. Multiple Error: 0 hex, 0 dec

5. Checksum Mask: 10 hex, 16 dec

6. Exception Value: 0 hex, 0 dec

7. Modbus Mode RTU: ON

8. Coil Register: 0 hex, $0 \mathrm{dec}$

9. Status Register: 0 hex, $0 \mathrm{dec}$

10. Hold Register \#01: 0 hex, 0 dec

11. Hold Register \#02: 0 hex, 0 dec

12. Hold Register \#03: 0 hex, 0 dec

13. Hold Register \#04: 0 hex, 0 dec

14. Hold Register \#05: 0 hex, 0 dec

15. Hold Register \#06: 0 hex, 0 dec

16. Hold Register \#07: 0 hex, 0 dec

17. Hold Register \#08: 0 hex, 0 dec

18. Hold Register \#09: 0 hex, 0 dec

19. Hold Register \#10: 0 hex, 0 dec

20. Hold Register \#11: 0 hex, 0 dec
21. Hold Register \#12: 0 hex, 0 dec

22. Hold Register \#13: 0 hex, 0 dec

23. Hold Register \#14: 0 hex, 0 dec

24. Hold Register \#15: 0 hex, 0 dec

25. Hold Register \#16: 0 hex, 0 dec

26. Hold Register \#17: 0 hex, 0 dec

27. Hold Register \#18: 0 hex, 0 dec

28. Hold Register \#19: 0 hex, 0 dec

29. Hold Register \#20: 0 hex, 0 dec

30. Mux Address: 1 hex, 1 dec

31. TC Temperature: $\mathbf{1 3 0 . 0 0}$

32. Temperature Mux Offset: $\mathbf{5 . 0 0}$

33. Temperature Register Offset: 1.00

34. Selected Address: 1 hex, 1 dec

35. Selected Register: OF hex, 15 dec

36. Selected TC Temperature: 0.00 
HNF-2792 Rev. 0

\begin{tabular}{|l|ll|}
\hline $\begin{array}{l}\text { Test Procedure ID } \\
\text { UTP 07.08.00 -00 } \\
\text { Revision 0 }\end{array}$ & $\begin{array}{l}\text { TEST DESIGN SPECIFICATION ID: 07.08.00 -00 } \\
\text { TESTING PHASE: Acceptance Test }\end{array}$ & $\begin{array}{l}\text { TITLE: Westronics Driver Acceptance Test } \\
\text { PLATFORM: UNIX }\end{array}$ \\
\cline { 2 - 3 } & &
\end{tabular}

\section{Appendix C: Emulator Configuration for Single Checksum Errors}

Display Configuration Parameters WESTRONICS PARAMETERS
1. Code Operated Switch: OFF
2. Tx Delay Time: 0.00
3. Error Rate \%: $\mathbf{3 0 . 0 0}$
4. Multiple Error: 0 hex, 0 dec
5. Checksum Mask: 10 hex, $16 \mathrm{dec}$
6. Exception Value: 0 hex, 0 dec
7. Modbus Mode RTU: ON
8. Coil Register: 0 hex, 0 dec
9. Status Register: 0 hex, 0 dec
10. Hold Register \#01: 0 hex, 0 dec
11. Hold Register \#02: 0 hex, 0 dec
12. Hold Register \#03: 0 hex, 0 dec
13. Hold Register \#04: 0 hex, 0 dec
14. Hold Register \#05: 0 hex, 0 dec
15. Hold Register \#06: 0 hex, 0 dec
16. Hold Register \#07: 0 hex, 0 dec
17. Hold Register \#08: 0 hex, 0 dec
18. Hold Register \#09: 0 hex, 0 dec
19. Hold Register \#10: 0 hex, 0 dec

20. Hold Register \#11: 0 hex, 0 dec
21. Hold Register \#12: 0 hex, 0 dec
22. Hold Register \#13: 0 hex, 0 dec
23. Hold Register \#14: 0 hex, 0 dec
24. Hold Register \#15: 0 hex, 0 dec
25. Hold Register \#16: 0 hex, 0 dec
26. Hold Register \#17: . O hex, 0 dec
27. Hold Register \#18: - 0 hex, 0 dec
28. Hold Register \#19: 0 hex, 0 dec
29. Hold Register \#20: 0 hex, 0 dec
30. Mux Address: 1 hex, 1 dec
31. TC Temperature: 130.00
32. Temperature Mux Offset: $\quad \mathbf{5 . 0 0}$
33. Temperature Register Offset: 1.00
34. Selected Address: 1 hex, $1 \mathrm{dec}$
35. Selected Register: OF hex, 15 dec
36. Selected TC Temperature: 0.00

\section{Sample Output From Westronics Emulator for Single Checksum Error}

This example is for a Westronics emulator \#1, slot 1 . The actual port and Westronics station number may be different in testing. The displays were captured with the emulator options " $F$ " and " $S$ " turned on. The check sums are bolded.

Response to driver from emulator with valid check sum. There is a single poll and response. 
HNF-2792 Rev. 0

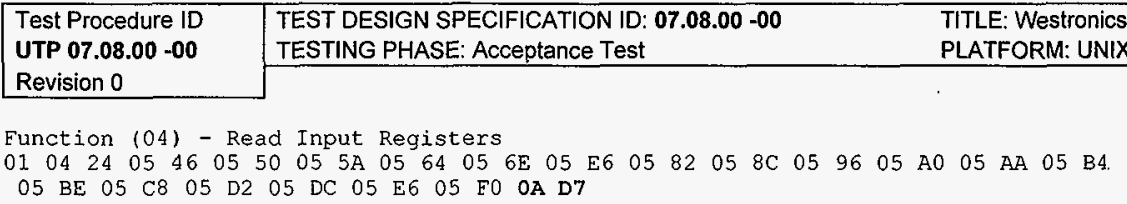

Response to driver from emulator with invalid check sum, followed by valid check sum. The poll with the invalid check sum is followed immediately by a retry from the driver.

Function (04) - Read Input Registers

$\begin{array}{llllllllllllllllllllllllllll}01 & 04 & 24 & 05 & 46 & 05 & 50 & 05 & 5 \mathrm{~A} & 05 & 64 & 05 & 6 \mathrm{E} & 05 & \mathrm{E} 6 & 05 & 82 & 05 & 8 \mathrm{C} & 05 & 96 & 05 & \mathrm{AO} & 05 & \mathrm{AA} & 05 & \mathrm{~B} 4\end{array}$

$05 \mathrm{BE} 05$ C8 05 D2 05 DC 05 E6 05 FO OA DD

Function (04) - Read Input Registers

$\begin{array}{llllllllllllllllllllllllllll}01 & 04 & 24 & 05 & 46 & 05 & 50 & 05 & 5 A & 05 & 64 & 05 & 6 E & 05 & E 6 & 05 & 82 & 05 & 8 C & 05 & 96 & 05 & A 0 & 05 & A A & 05 & B 4\end{array}$

$\begin{array}{llllllllllllll}05 & \mathrm{BE} & 05 & \mathrm{C} 8 & 05 & \mathrm{D} 2 & 05 & \mathrm{DC} & 05 & \mathrm{E} 6 & 05 & \mathrm{~F} 0 & \mathrm{OA} & \mathrm{D} 7\end{array}$ 
HNF-2792 Rev. 0

\begin{tabular}{|l|ll|}
\hline $\begin{array}{l}\text { Test Procedure ID } \\
\text { UTP 07.08.00 -00 }\end{array}$ & TEST DESIGN SPECIFICATION ID: 07.08.00 -00 & TITLE: Westronics Driver Acceptance Test \\
Revision 0 & TESTING PHASE: Acceptance Test & PLATFORM: UNIX \\
\cline { 2 - 3 } & &
\end{tabular}

\section{Appendix D: Emulator Configuration for Multiple Checksum Errors}

Display Configuration Parameters WESTRONICS PARAMETERS

1. Code Operated Switch: OFF

2. Tx Delay Time: 0.00

3. Error Rate \%: $\mathbf{3 0 . 0 0}$

4. Multiple Error: 1 hex, 1 dec

5. Checksum Mask: $10 \mathrm{hex}, 16 \mathrm{dec}$

6. Exception Value: 0 hex, 0 dec

7. Modbus Mode RTU: ON

8. Coil Register: 0 hex, 0 dec

9. Status Register: 0 hex, $0 \mathrm{dec}$

10. Hold Register \#01: 0 hex, 0 dec

11. Hold Register \#02: 0 hex, 0 dec

12. Hold Register \#03: 0 hex, 0 dec

13. Hold Register \#04: 0 hex, 0 dec

14. Hold Register \#05: 0 hex, 0 dec

15. Hold Register \#05: 0 hex, 0 dec

16. Hold Register \#07: 0 hex, 0 dec

17. Hold Register \#08: 0 hex, 0 dec

18. Hold Register \#09: 0 hex, 0 dec

19. Hold Register \#10: 0 hex, 0 dec

20. Hold Register \#11: 0 hex, 0 dec
21. Hold Register \#12: 0 hex, 0 dec

22. Hold Register \#13: 0 hex, 0 dec

23. Hold Register \#14: 0 hex, 0 dec

24. Hold Register \#15: 0 hex, 0 dec

25. Hold Register \#16: 0 hex, 0 dec

26. Hold Register \#17: 0 hex, 0 dec

27. Hold Register \#18: 0 hex, 0 dec

28. Hold Register \#19: 0 hex, 0 dec

29. Hold Register \#20: 0 hex, 0 dec

30. Mux Address: 1 hex, 1 dec

31. TC Temperature: 130.00

32. Temperature Mux Offset: $\mathbf{5 . 0 0}$

33. Temperature Register Offset: 1.00

34. Selected Address: 1 hex, 1 dec

35. Selected Register: OF hex, 15 dec

36. Selected TC Temperature: 0.00

\section{Sample Output From Westronics Emulator for Multiple Checksum Errors}

This example is for a Westronics emulator \#1, slot 1 . The actual port and Westronics station number may be different in testing. The displays were captured with the emulator options " $F$ " and " $S$ " turned on. The check sums are bolded.

Response to driver from emulator with valid check sum. There is a single poll and response. 
HNF-2792 Rev. 0

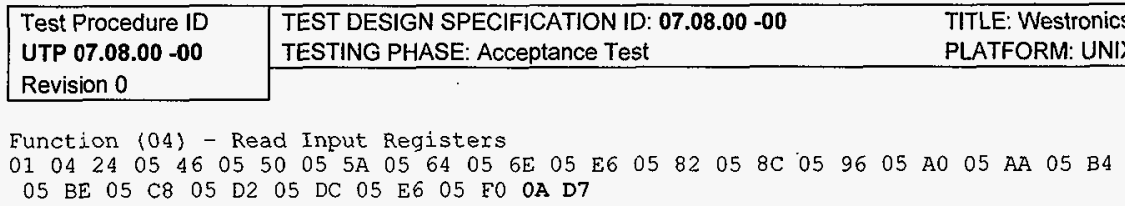

Response to driver from emulator with invalid check sum, followed by invalid check sum. The poll with the invalid check sum is followed immediately by a retry from the driver. After the second bad checksum there will be an error in $\mathrm{G} 2$. There will be no more retries until the next scheduled poll time.

Function (04) - Read Input Registers

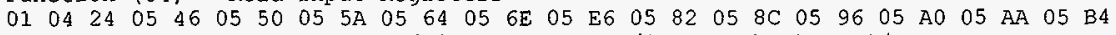
05 BE 05 C8 05 D2 05 DC 05 E6 05 F0 0A DD /* Bad Checksum */

Function (04) - Read Input Registers

$\begin{array}{lllllllllllllllllllllllllll}01 & 04 & 24 & 05 & 46 & 05 & 50 & 05 & 5 \mathrm{~A} & 05 & 64 & 05 & 6 \mathrm{E} & 05 & \mathrm{E} 6 & 05 & 82 & 05 & 8 \mathrm{C} & 05 & 96 & 05 & \text { AO } & 05 & \mathrm{AA} & 05 & \mathrm{~B} 4\end{array}$

05 BE 05 C8 05 D2 05 DC 05 E6 05 F0 OA DD /* Bad Checksum */ 


\begin{tabular}{|l|ll|}
\hline $\begin{array}{l}\text { Test Procedure ID } \\
\text { UTP 07.08.00 -00 }\end{array}$ & TEST DESIGN SPECIFICATION ID: 07.08.00-00 & TITLE: Westronics Driver Acceptance Test \\
Revision 0 & TESTING PHASE: Acceptance Test & PLATFORM: UNIX Page 22 of 27 \\
\cline { 2 - 3 } & &
\end{tabular}

\section{Appendix E: Emulator Configuration for Single Exception Error}

Table 1. Valid Exception Codes, Names, and Meanings

\begin{tabular}{|c|c|c|}
\hline Code & Name & Meaning \\
\hline 01 & lllegal Function & The function code received in the query is not an allowable action for the slave. \\
\hline 02 & Illegal Data Address & The data address received in the query is not an allowable address for the slave. \\
\hline 03 & Illegal Data Value & A value contained in the query data field is not an allowable value for the slave. \\
\hline 04 & Slave Device Failure & An unrecoverable error occurred while the slave was attempting to perform the requested action. \\
\hline 05 & Acknowledge & The slave has accepted a request and is processing it but a long duration time is required. \\
\hline 06 & Slave Device Busy & The slave is processing a long-duration program command. \\
\hline 07 & Negative Acknowledge & The slave cannot perform the program function received in the query. \\
\hline 08 & Memory Parity Error & The slave attempted to read e3xtended memory but detected a parity error in the memory. \\
\hline
\end{tabular}

Display Configuration Parameters WESTRONICS PARAMETERS
1. Code Operated Switch: OFF
2. Tx Delay Time: 0.00
3. Error Rate \%: $\mathbf{3 0 . 0 0}$
4. Multiple Error: 0 hex, 0 dec
5. Checksum Mask: 0 hex, 0 dec
6. Exception Value: 01 hex, 1 dec
7. Modbus Mode RTU: ON
8. Coil Register: 0 hex, 0 dec
9. Status Register: 0 hex, 0 dec
10. Hold Register \#01: 0 hex, 0 dec
11. Hold Register \#02: 0 hex, $0 \cdot d e c$
12. Hold Register \#03: 0 hex, 0 dec
13. Hold Register \#04: 0 hex, 0 dec
14. Hold Register \#05: 0 hex, 0 dec
15. Hold Register \#06: 0 hex, 0 dec
16. Hold Register \#07: 0 hex, 0 dec
17. Hold Register \#08: 0 hex, 0 dec
18. Hold Register \#09: 0 hex, 0 dec
19. Hold Register \#10: 0 hex, 0 dec
20. Hold Register \#11: 0 hex, 0 dec
21. Hold Register \#12: 0 hex, 0 dec
22. Hold Register \#13: 0 hex, 0 dec
23. Hold Register \#14: 0 hex, 0 dec
24. Hold Register \#15: 0 hex, 0 dec
25. Hold Register \#16: 0 hex, 0 dec
26. Hold Register \#17: 0 hex, 0 dec
27. Hold Register \#18: 0 hex, 0 dec
28. Hold Register \#19: 0 hex, 0 dec
29. Hold Register \#20: 0 hex, 0 dec
30. Mux Address: 1 hex, 1 dec
31. TC Temperature: $\mathbf{1 3 0 . 0 0}$
32. Temperature Mux Offset: $\mathbf{5 . 0 0}$
33. Temperature Register Offset: 1.00
34. Selected Address: 1 hex, 1 dec
35. Selected Register: OF hex, 15 dec
36. Selected TC Temperature: 0.00 


\begin{tabular}{l|ll|}
\hline $\begin{array}{l}\text { Test Procedure ID } \\
\text { UTP 07.08.00 -00 } \\
\text { Revision 0 }\end{array}$ & $\begin{array}{l}\text { TEST DESIGN SPECIFICATION ID: 07.08.00 -00 } \\
\text { TESTING PHASE: Acceptance Test }\end{array}$ & $\begin{array}{l}\text { TITLE: Westronics Driver Acceptance Test } \\
\text { PLATFORM: UNIX }\end{array}$ \\
\cline { 2 - 3 } & &
\end{tabular}

\section{Sample Output From Westronics Emulator for Single Exception Error}

This example is for a Westronics emulator \#1, slot 1. The actual port and Westronics station number may be different in testing. The displays were captured with the emulator options " $F$ " and " $S$ " turned on.

Response to driver from emulator with valid poll and response.

Function (04) - Read Input Registers

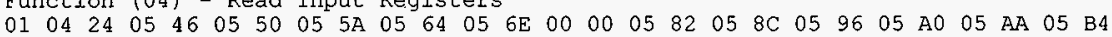

05 BE 05 C8 05 D2 05 DC 05 E6 05 FO

Response to driver from emulator with exception code. When the request is rejected the high bit in byte 2 is set on (80h) and the exception code is set in the lower bits of byte 2 . In this example a exception code of $4 \mathrm{~h}$ is returned so the second byte is $84 \mathrm{~h}(80 \mathrm{~h}+4 \mathrm{~h})$.

Function (04) - Read Input Registers

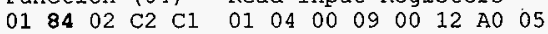


HNF-2792 Rev. 0

\begin{tabular}{|l|ll|}
\hline $\begin{array}{l}\text { Test Procedure ID } \\
\text { UTP 07.08.00 -00 } \\
\text { Revision 0 }\end{array}$ & $\begin{array}{l}\text { TEST DESIGN SPECIFICATION ID: 07.08.00-00 } \\
\text { TESTING PHASE: Acceptance Test }\end{array}$ & TITLE: Westronics Driver Acceptance Test \\
\cline { 2 - 3 } & & PLATFORM: UNIX Page 24 of 27 \\
\hline
\end{tabular}

Appendix F: Emulator Configuration for Station Mismatch Error

Display Configuration Parameters WESTRONICS PARAMETERS

1. Code Operated Switch: OFF

2. Tx Delay Time: 0.00

3. Error Rate \%: $\quad 30.00$

4. Multiple Error: 1 hex, 1 dec

5. Checksum Mask: 0 hex, 0 dec

6. Exception Value: 0 hex, $0 \mathrm{dec}$

7. Modbus Mode RTU: ON

8. Coil Register: 0 hex, 0 dec

9. Status Register: 0 hex, $0 \mathrm{dec}$

10. Hold Register \#01: 0 hex, 0 dec

11. Hold Register $\# 02$ : 0 hex, 0 dec

12. Hold Register \#03: 0 hex, 0 dec

13. Hold Register \#04: 0 hex, 0 dec

14. Hold Register \#05: 0 hex, 0 dec

15. Hold Register \#06: 0 hex, 0 dec

16. Hold Register \#07: 0 hex, 0 dec

17. Hold Register \#08: 0 hex, 0 dec

18. Hold Register \#09: 0 hex, 0 dec

19. Hold Register \#10: 0 hex, 0 dec

20. Hold Register \#11: 0 hex, 0 dec
21. Hold Register \#12: 0 hex, 0 dec

22. Hold Register \#13: 0 hex, 0 dec

23. Hold Register \#14: 0 hex, 0 dec

24. Hold Register \#15: 0 hex, 0 dec

25. Hold Register \#16: 0 hex, 0 dec

26. Hold Register \#17: 0 hex, 0 dec

27. Hold Register \#18: 0 hex, 0 dec

28. Hold Register \#19: 0 hex, 0 dec

29. Hold Register \#20: 0 hex, 0 dec

30. Mux Address: 22 hex, 2 dec

31. TC Temperature: 130.00

32. Temperature Mux Ofiset: $\mathbf{5 . 0 0}$

33. Temperature Register Offset: 1.00

34. Selected Address: 1 hex, $1 \mathrm{dec}$

35. Selected Register: 15 hex, 15 dec

36. Selected TC Temperature: 0.00

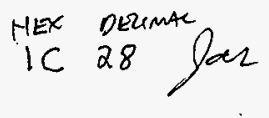


Test Procedure ID UTP 07.08.00 -00

Revision 0
TEST DESIGN SPECIFICATION ID: 07.08.00 -00

TESTING PHASE: Acceptance Test
TITLE: Westronics Driver Acceptance Test PLATFORM: UNIX

\section{Sample Output From Westronics Emulator for Station Mismatch Error}

This example is for a Westronics emulator \#1, slot 1. The actual port and Westronics station number may be different in testing. The displays were captured with the emulator options " $F$ ", " $R$ ", and " $S$ " turned on. The display has been reformatted for clarity.

The first character sent by either device is the station number. In this example the driver is asking for station \#1. The emulator is responding as station \#2. G2 should report this as an error immediately.

010400090012 AO 05 * Request for read from station 1 *

Function (04) - Read Input Registers

$\begin{array}{llllllllllllllllllllllllllll}02 & 04 & 24 & 05 & 46 & 05 & 50 & 05 & 5 A & 05 & 64 & 05 & 6 E & 00 & 00 & 05 & 82 & 05 & 8 \mathrm{C} & 05 & 96 & 05 & A .0 & 05 & \mathrm{AA} & 05 & \mathrm{~B} 4\end{array}$

$05 \mathrm{BE} 05 \mathrm{C} 805 \mathrm{D} 205 \mathrm{DC} 05 \mathrm{E} 605 \mathrm{FO}$ AO 61 /* Response from station 2 */ 
HNF-2792 Rev. 0

\begin{tabular}{|l|ll|}
\hline $\begin{array}{l}\text { Test Procedure ID } \\
\text { UTP 07.08.00 -00 } \\
\text { Revision 0 }\end{array}$ & $\begin{array}{l}\text { TEST DESIGN SPECIFICATION ID: 07.08.00 -00 } \\
\text { TESTING PHASE: Acceptance Test }\end{array}$ & TITLE: Westronics Driver Acceptance Test \\
\cline { 2 - 3 } & & PLATFORM: UNIX Page 26 of 27 \\
\hline
\end{tabular}

\section{ACCEPTANCE TEST PROCEDURE COVER SHEET}

APPROVAL OF TEST PROCEDURE

$\begin{array}{lc}\text { A Bacus } & 6 / 22 / 98 \\ \text { DA Barnes TMACS Cognizant Engineer } & 6 / 22 / 48 \\ \text { J.A. Glasscock TMACS Project Manager } & 6 / 24\end{array}$

Arscock macs project Manager

Execution Nymber for this Test : 1

Tester:

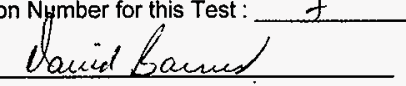

Execution Test Date/Time: 14001 Jucy 40

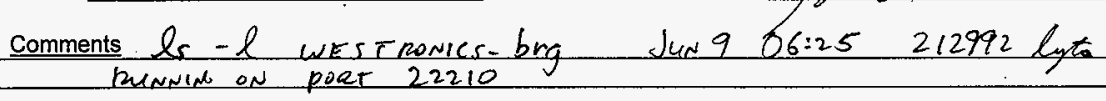

TEST was (circle one) Successful Unsuccessful " Re-test

\section{CERTIFICATION OF SATISFACTORY EXECUTION}

All of the test cases for this test procedure have been tested and all anomalies for this test procedure have been resolved.

DA Barnes TMACS Cognizant Engineer


SURV SIS Walkthrough Log

$$
\text { p. }(\not / \text { / Page } 27 \text { of } 27
$$

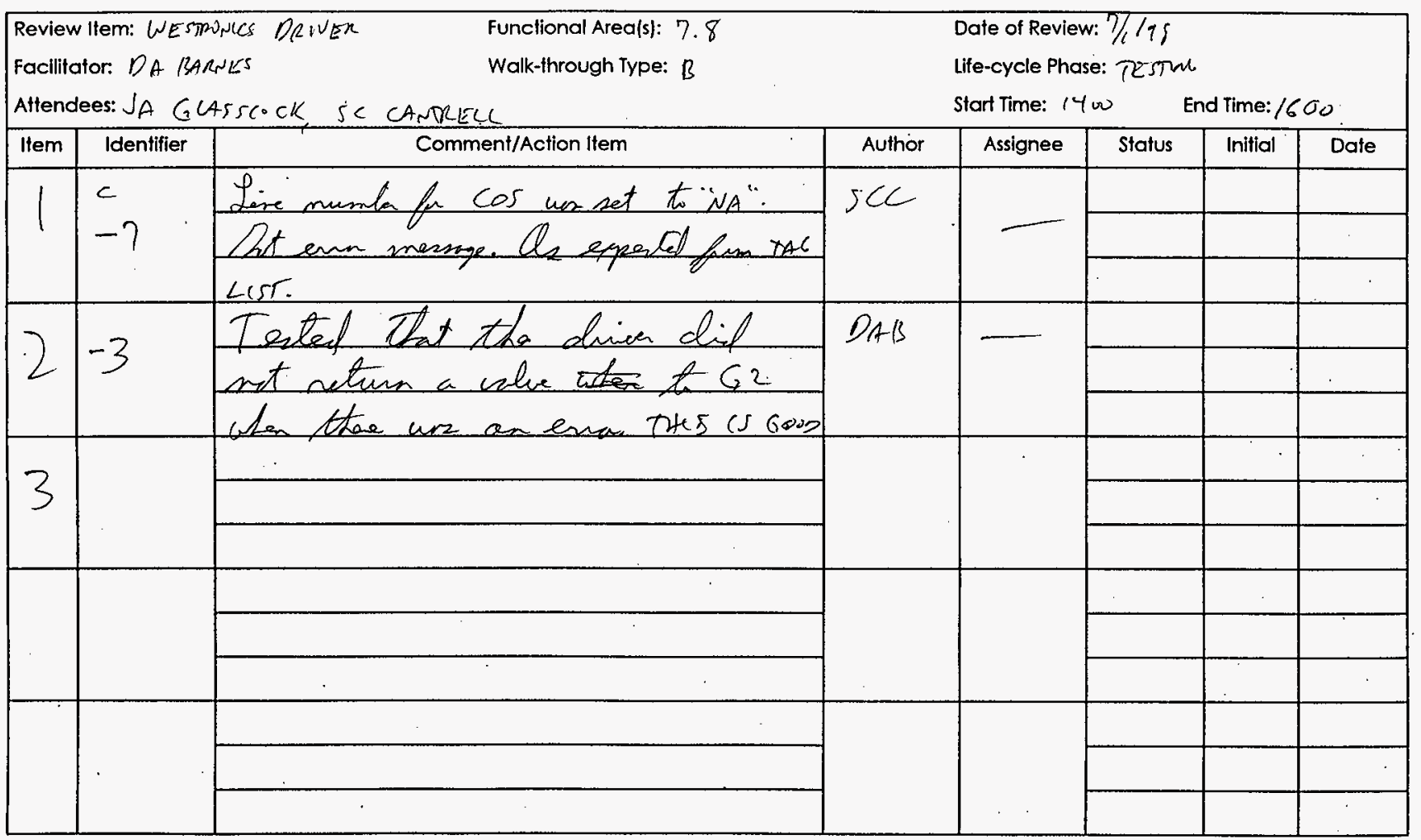

Walk through types: A - One-on-one peer. B - One-on-one user. C - One-on-one management D - Formal task group E - Formal program group $\mathrm{F}$ - Customer management $\mathrm{G}$ - Change control board $\mathrm{H}$ - External 


\section{DISTRIBUTION SHEET}

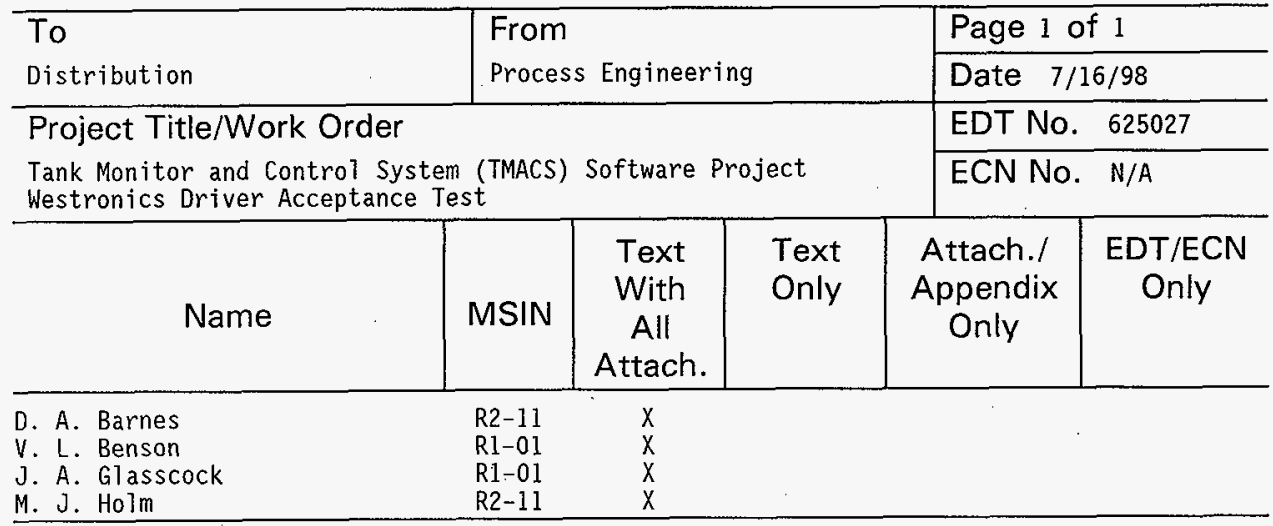

